\title{
Eleocharis carniolica W. D. J. Koch, new species in flora of Montenegro
}

\author{
Snežana Vuksanovićc,*(D), Nada Bubanja1 \& Christian Berg² (i)
}

Key words: Eleocharis carniolica, Semolj, Montenegro, flora.

Ključne besede: Eleocharis carniolica, Semolj, Črna gora, flora.

\begin{abstract}
During floristic research of acidic bogs, calcareous fens and seasonally flooded (periodically inundated) grassy places in beech forests in Semolj region, Eleocharis carniolica W. D. J. Koch was found, which was the first record of that species in vascular plant flora of Montenegro. In surrounding countries, this species was recorded in Bosnia and Herzegovina, Croatia, Slovenia and Albania. This paper provides description of sites, habitat and ecology of Eleocharis carniolica W. D. J. Koch in Montenegro.

Izvleček

Med florističnimi raziskavami kislih visokih in karbonatnih nizkih barij v okolici Semolja smo našli vrsto Eleocharis carniolica W. D. J. Koch, kar je prvi podatek o pojavljanu te vrste v Črni gori. V sosednjih državah so to vrsto našli v Bosni in Hercegovini, na Hrvaškem, v Sloveniji in v Albaniji. V članku podajamo opis rastišča in ekologijo vrste Eleocharis carniolica W. D. J. Koch v Črni gori.
\end{abstract}

Received: 27.3. 2018

Revision received: 17. 1. 2019

Accepted: 21. 1. 2019

1 Natural History Museum of Montenegro, Vojvode Bećir Bega Osmanagića square 16, 81000 Podgorica, Montenegro.

2 Institute of Biology, University of Graz, 8010 Graz, Austria.

* Corresponding author. E-mail: vukss@t-com.me 


\section{Introduction}

Eleocharis is a cosmopolitan genus represented with 200 to 250 species in World (Govaerts et al. 2007), with as much as 145 species in America (González-Elizondo \& Tena-Flores 2000). In Europe, genus is represented with 15 taxa (Walters 1980), six of which occur in Montenegro - E. acicularis (L.) Roem. \& Schult., E. palustris (L.) R. Br., E. mamillata H.Lindb. subsp. mamillata., E. mamillata subsp. austriaca (Hayek) Strandh., E. uniglumis (Link) Schult., E. quinqueflora (Hartmann) O. Schwarz (Rohlena 1942, Birks \& Walters 1973, Parolly 1995, Hadžiablahović 2004, Pulević 2005, Blaženčić 2007). The supraspecific classification of the genus Eleocharis was recently critically assessed on a worldwide basis (González-Elizondo \& Peterson 1997). The new circumscription of several groups proved to be quite different compared with that adopted by earlier authors, including Svenson (1929, 1932, 1934, 1937, 1939), the latest monographer of the genus (Verloove 2015). According to their new system which includes 4 subgenera, 7 sections, 8 series, and 7 subseries the Montenegrian representatives of Eleocharis belong to the subgenera Zinserlingia T. V. Egorova (E. quinqueflora), Scirpidium (Nees) Kukkonen (E. acicularis) and Eleocharis. The last one is further divided in section Eleocharis [with series Eleocharis (subseries Eleocharis: E. palustris, E. mamillata, E. austriaca and E. uniglumis) and series Multicaules (Beauverd) Svenson ex J. Kern (E. carniolica)]. Eleocharis carniolica W. D. J. Koch is a rare species that is protected at European level. It is listed on Annex I of the Bern Convention (Anonymous 1979) and Habitat Directive (Anonymus 1992, Appendix IIb and Appendix IVb). This species is also a remarkable so called "community interest" species of the Natura 2000 ecological network (Barina et al. 2011). General distribution of E. carniolica species is limited to the central, east and southeast of Europe. Eleocharis carniolica populates frequently disturbed wet habitats and pioneer vegetation of marsh annuals among them wet fields and river banks. (Lansdown, R.V. 2013). It grows in wet and marshy meadows, in damp places in forests (moist forest roads and along the paths) and at occasionally flooded places on sandy to mostly clay and clay bases on the riverside, ponds and water reservoirs (Vreš, 2003). E. carniolica appears in associations of the coastal alliance Fimbristylion bisumbellate and continental Nanocyperion (Topić 2005). It is a declining native species in large parts of Europe and is considered as least concern (LC) according to IUCN Red List Category (EU 27, Lansdown, R.V. 2013). In Croatia and Bulgaria this plant is protected (Biodiversity Act 2002, Anonymous 2013) and referred like endangered
EN (Topić 2005, Stoeva 2009). E. carniolica is on the red list of endangered species in Italy (Rossi et al. 2013). In Slovenia has also been protected and recorded on the list of vulnerable species (Anonymous, 2002). In Austria, the species is endangered according to the rather old Red List (Niklfeld \& Schratt-Ehrendorfer 1999), and the conservation status has deteriorated. Also, E. carniolica is considered as vulnerable or endangered in all countries of the Carpathian chain (Witkowski et al. 2003). Recently it has been found in Albania (Barina et al. 2011).

\section{Material and methods}

Specimens of Eleocharis carniolica were collected in July 2017 and September 2018 in area of acidic peat bogs and beech forest at the Semolj locality (Central Montenegro). Collected material was dried and stored in the collection of flowering plants and ferns of Natural History $\mathrm{Mu}$ seum of Montenegro (Inventory numbers: 7675; 7760; 9192; 9193). Geocoordinates of every location on which the species was found have been recorded with GPS device Garmine-TrexVista. All relevant literature was used for determination (Walters 1980, Casper \& Krausch 2008). Names of all species follow Euro+Med PlantBase nomenclature. NATURA 2000 habitats are congruent with European Union habitat interpretation handbook (EUROPEAN COMMISSION DIRECTORATES GENERAL, 2007), as well as with Types catalogue of Montenegro habitats significant for European Union (Petrović et al., 2012).

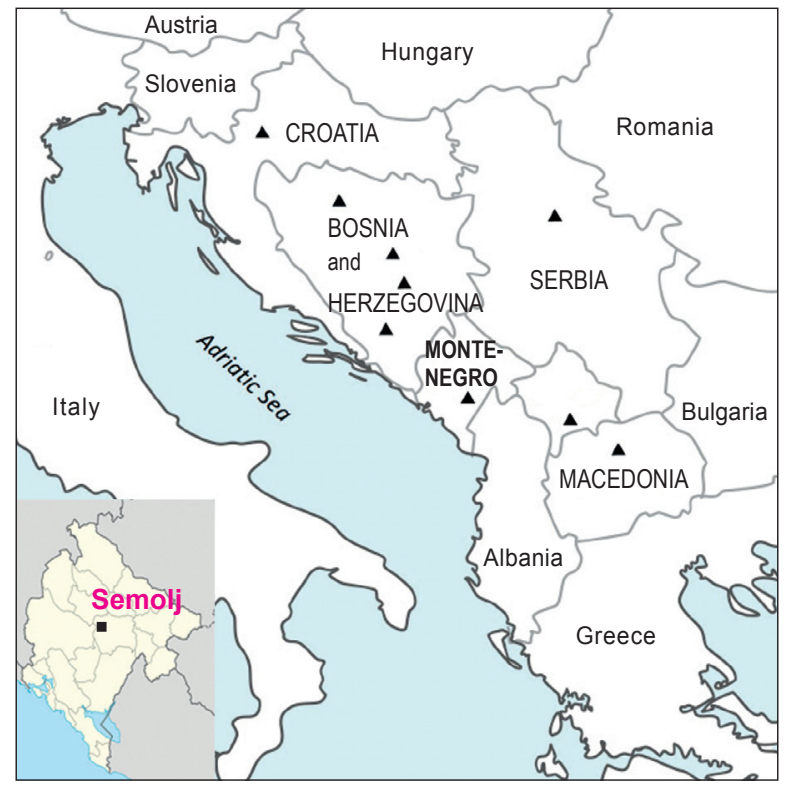

Figure 1: Research area.

Slika 1: Preučevano območje. 


\section{Research area}

Saddle Semolj is located in the central part of Montenegro, on south-western slopes of Sinjajevina mountain, at 1497 meters a.s.l. It clearly separates the highest point of Sinjajevina, Babin Zub from Lola Mountain and Moračke mountains. Morača, the longest and the most water abounded river of this area, is located on south-west of Semolj and belongs to Adriatic basin. Tušina river, which belongs to Black Sea basin, is located in north-east side of Morača, so the Semolj represents their watershed (Figure 1). Rocks, which are structure parts of this locality, are from Triassic age and are made of limestone in contact with andesites and keratophyses (Kalezić et al. 1973). Few smaller transitional peat bogs and calcareous fens were registered on Semolj. According to Jovanović et al. (1986) ass. Abieti-Fagetum (Ht. 1938) Treg. 1957 s. lat. is cited for Semolj area. A snow-forested (boreal) climate, without a dry season during the year, occurs in this area, and it affects the development of typical mountain vegetation (Burić et al., 2012).

\section{Results}

During the years 2017 and 2018 floristic research were carried out in quaking bogs and beech forest on Semolj saddle. Eleocharis carniolica species has been recorded on four localities: Semolj 1 at N 42 $5432.45^{\prime \prime}$, E19 $16^{\prime} 24.98^{\prime \prime}$ (N. Bubanja, 11.07.2017 Inventory number: 7675), Semolj 2 at N 4254'24.05”, E 19¹6'26.13" (S. Vuksanović, 08.07. 2017 Inventory number: 7760) (Figure 2, Figure 3), Semolj 3 at N 42 54'25.42”, E19 16'38.01” (S. Vuksanović, 06.09. 2018 Inventory number: 9192) (Figure 6) and Bare at N 42.54'14.68", E19 ${ }^{\circ} 17^{\prime 1} 14.36$ ”, (S. Vuksanović 06.09. 2018 Inventory number: 9193) (Figure 7). The first two localities are on quaking bogs which belongs to NATURA 2000 habitat

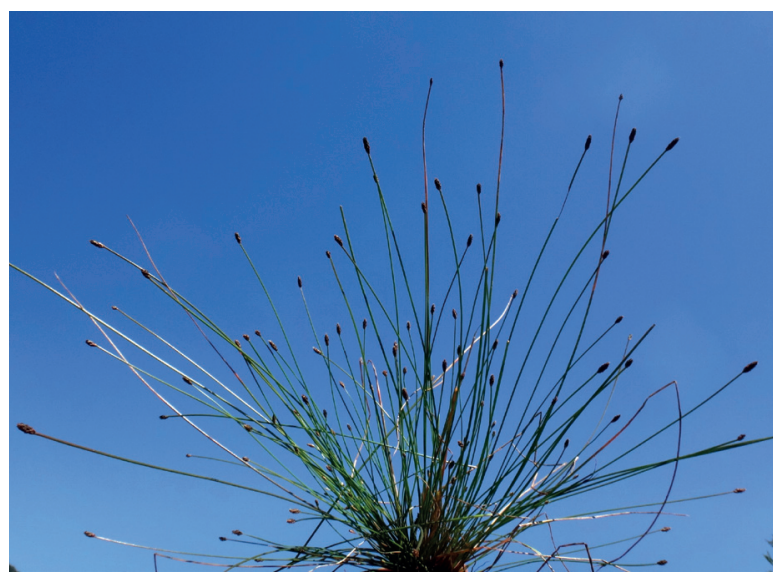

Figure 2 (Slika 2): Eleocharis carniolica W. D. J. Koch (Photo: C. Berg).

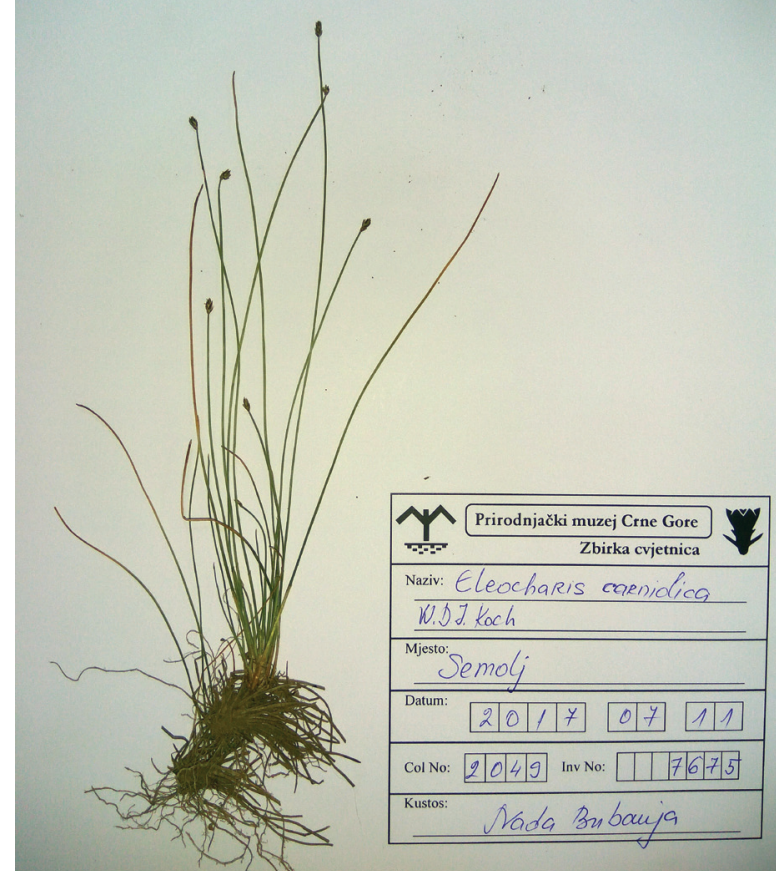

Figure 3: Herbar specimen (Photo: N. Bubanja). Slika 3: Herbarijski primerek (Foto: N. Bubanja).

7140 Transition mires and quaking bogs while Semolj 2 features also NATURA 2000 habitat 7230 Alkaline fens (Petrović $\&$ al. 2012). Both are surrounded by thick forest consisted of community of beech (Fagus sylvatica L.) and mountain maple (Acer heldreichii Orph. ex Boiss.). Localities Semolj 3 and Bare are grassy planes in beech forest subjected to seasonally flooding. Semolj 3 is the situated in beech forest surrounded the quaking bogs while locality Bare occupies the southwest slopes of hill on the saddle Semolj at an elevation of $1650 \mathrm{~m}$ above sea level. Permanent water is present the most part of year, while during the summer and early autumn these wood pastures are dry. In area shown at locality Semolj 1 in Figure 4 and locallity Semolj 3 in Figure 6 the species covers over 30 square meters, at locality Bare in Figure 7 about 10 square meters while in area at locality Semolj 2 shown in Figure 5 only and 2 square meters. Eleocharis carniolica at first locality grows almost throughout the entire bog vegetation gradient, and mostly on swamping borders of water surfaces. These parts of bog include several pools of various sizes characterized by the presence of aquatic and wetland species e.g. Nuphar lutea (L.) Sm. and Potamogeton gramineus L. Further. In most cases, the bog margins are occupied by: Juncus articulatus L., Juncus capitatus Weigel, Juncus bufonius L., Carex echinata Murray, Carex flava L., Carex lasiocarpa Ehrh., Carex nigra (L.) Reichard, Carex rostrata Stokes, Menyanthes trifoliata L., Pinguicula balcanica Casper, Caltha palustris L., Parnas- 


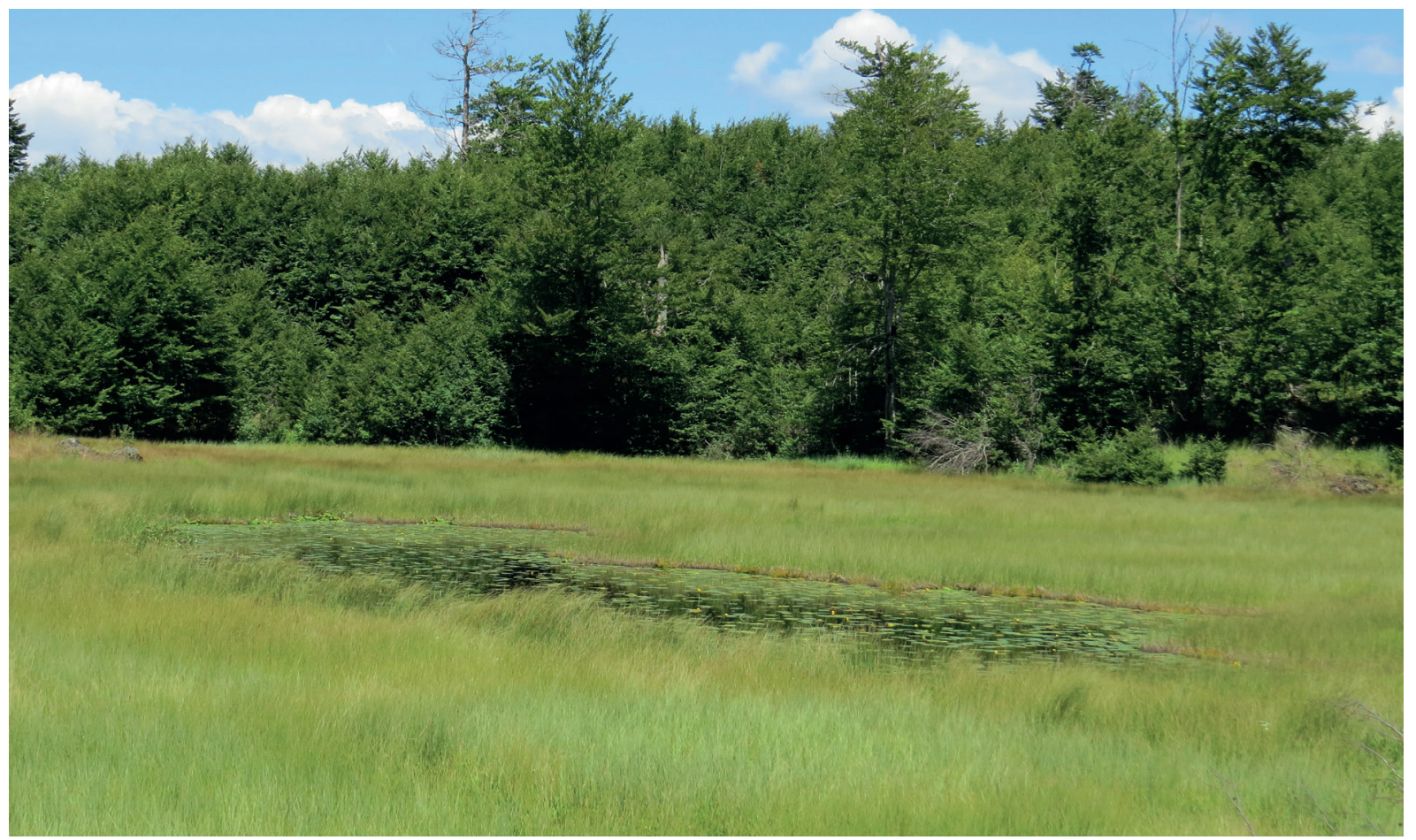

Figure 4: Quaking bogs in Semolj 1 (Photo: N. Bubanja).

Slika 4: Plavajoče visoko barje Semolj 1 (Foto: N. Bubanja).

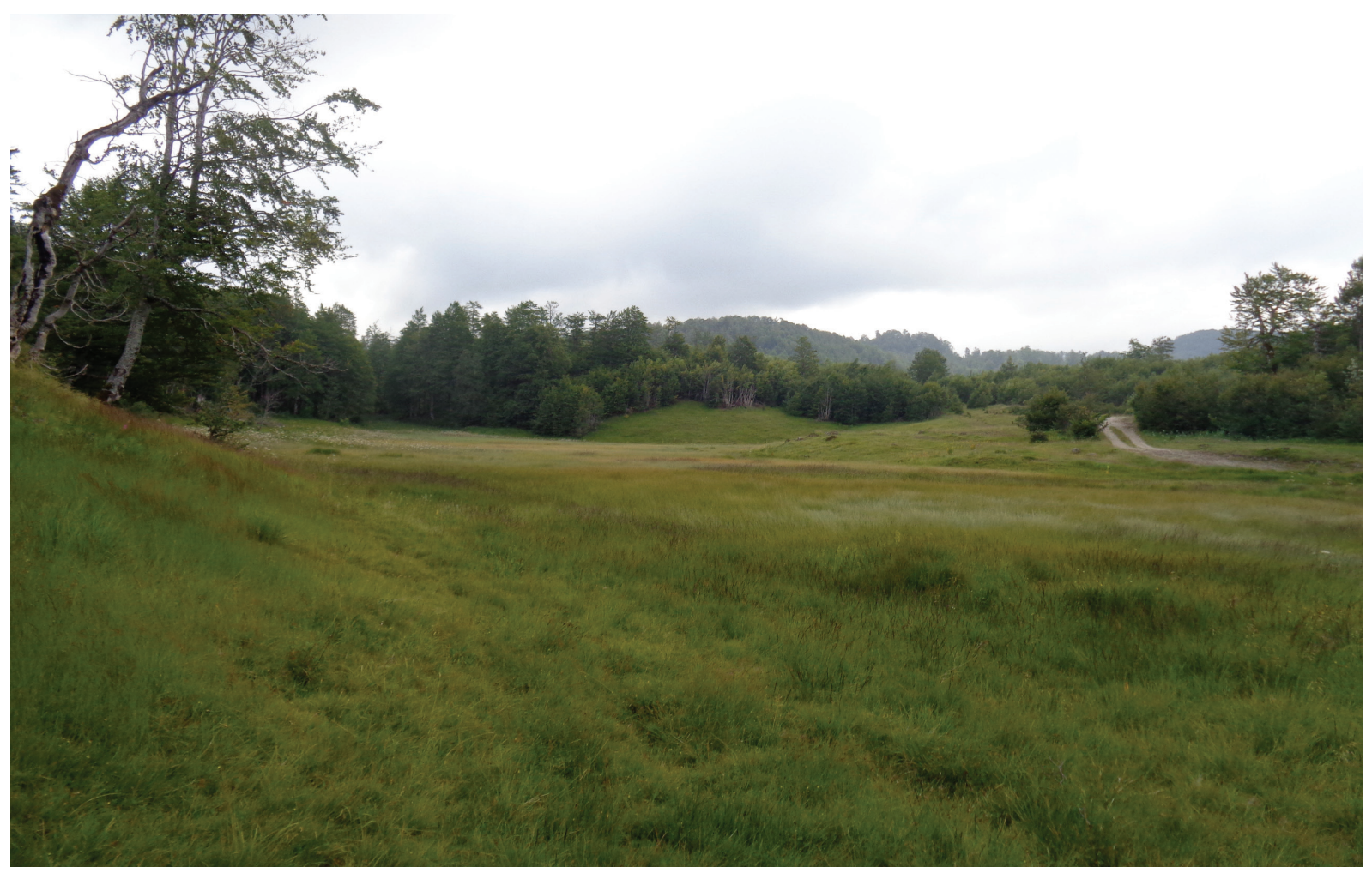

Figure 5: Quaking bogs in Semolj 2 (Photo: S. Dragićević)

Slika 5: Plavajoče visoko barje Semolj 2 (Foto: S. Dragićević). 


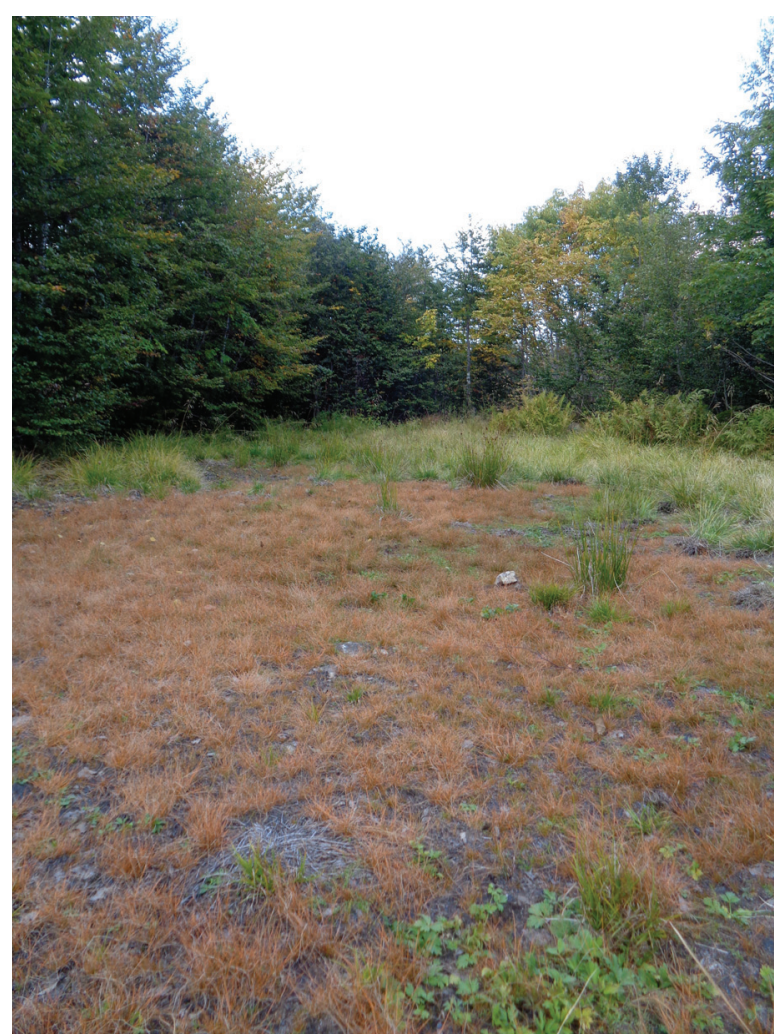

Figure 6 (Slika 6): Semolj 3 (Photo/Foto: S. Vuksanović).

sia palustris L., Gymnadenia frivaldii Hampe ex Griseb., Dactylorhiza cordigera subsp. bosniaca (Beck) Soó, Dactylorhiza majalis (Rchb.) P.F.Hunt \& Summerh., Sphagnum spp., etc. The second investigated bog locality is just a part of a mire complex comprising alkaline fen, transitional bog and hydrophilous tall herb fringe community. In this locality, E. carniolica occurs in margin of calcareous fen with Carex flava L., Carex leporina L., Carex echinata Murray, Carex panicea L., Carex nigra (L.) Reichard, Blysmmus compresus (L.) Link, Parnassia palustris L., Dactylorhiza cordigera subsp. bosniaca (Beck) Soó, Pinguicula balcanica Casper, Molinia caerulea (L.) Moench and others. The last two localities (Semolj 3 and Bare) are disturbed grassy places in beech woods, seasonally inundated. In first of them (Semolj 3) Eleocharis carniolica grows on acidic poor sandy soil surrounding with Juncus effusus L., Carex leporina L., Deschampsia caespitosa (L.) P. Beauv., Ranunculus repens L., Galium palustre L., Lysimachia nummularia L., Carex pallescens L., Spergularia rubra (L.) J. Presl \& C. Presl., Cardamine pratensis L., Polygonum aviculare L, Gnaphalium uliginosum L. Locality Bare populates with dense tufts of Deschampsia ceaspitosa (L.) P. Beauv. On the margin, sandy substrate occupies tussocks of Eleocharis carniolica accompanied with Carex

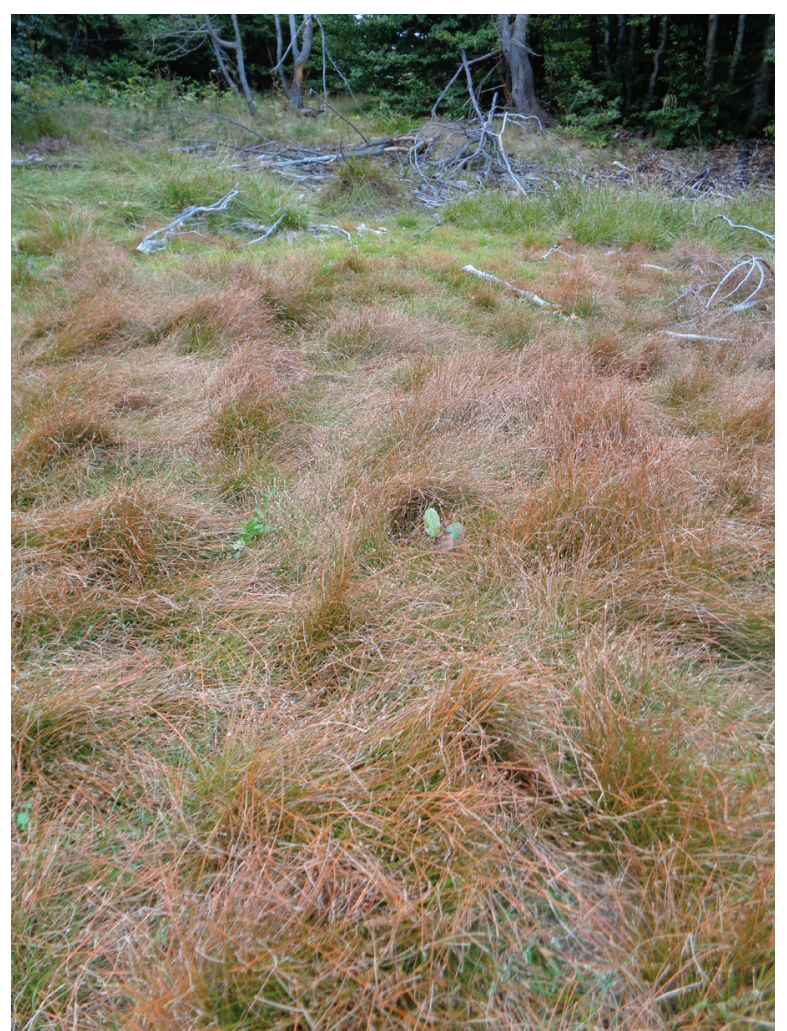

Figure 7: Tussocks of Eleocharis carniolica on locality Bare. Slika 7: Šopi vrste Eleocharis carniolica na lokaliteti Bare.

leporina L., Ranunculus repens L., Potentilla recta L. and Hypericum maculatum Crantz. On the most positions, populations of Eleocharis carniolica are dense but represented by a small nubmer of specimens.

\section{Discussion}

Eleocharis carniolica is widespread and locally common, however it does show local declines in many parts of Europe (Lansdown 2013). It is on Red lists of endangered species, vulnerable or near threatened species in majority of European countries: Croatia (Topić 2005), Bulgaria (Stoeva 2009), Italy (Rossi et al. 2013), Slovenia (Anonymus 2002), Slovakia (Turis et al. 2014), Poland (Kopeć \& Michalska-Hejduk 2012), Hungary (Kiraly 2007) etc. In most of the countries of Europe Eleocharis carniolica is found in similar habitats, mainly in swampy and seasonally flooded semiaquatic habitats. Such habitats are rare in most of the countries of Europe, and often in strong decline due to floodplain regulation and draining. It grows in several localities in Croatia along the ponds, mainly in the association Dichostyli-Fimbristyletum dichotomae H-ić, 1953, class Isoëto-Nanojuncetea Br.-Bl. \& Tx. (1943) (Protection of Biodiversity of the Sava River Basin 
Floodplains 2008-2009) with one spot in forest association Sphagno-Piceetum s.l. Vukelić 2012 (Šegota \& Alegro 2016). In Slovenia, it was found at several localities within the class Isoëto-Nanojucetea Br.-Bl. \& Tx. 1943 in ass. Molinietum caeruleae s. lat., and association with Cyperetum flavescentis (Vreš 2004). In Croatia, Bosnia and Herzegovina, as in Slovenia, this species is present at NATURA 2000 habitats 3130 Oligotrophic to mesotrophic standing waters with vegetation of Littorelletea uniflora and/or Isoëto-Nanojuncetea (Protection of Biodiversity of the Sava River Basin Floodplains 2008-2009). Recently, Eleocharis carniolica has been found in Albania in a shallow depression on serpentine baserock with more or less closed vegetation at an elevation of nearly $1700 \mathrm{~m}$ above sea level (Barina et al. 2011). In Italy this species builds association Junco tenagejae - Eleocharietum carniolicae ass. nova, while in Romania it is found in associations Agrostetum caninae Harg 1942 and Juncetum effuse Soó (1931) 1949 (Lastrucci \& Beccatini 2009, Stzmari et al. 2014). In Poland, this species is present in Natura 2000 habitats 3130 Oligotrophic to mesotrophic standing waters with vegetation of Littorelletea uniflora and/or Isoëto-Nanojuncetea, 3270 Rivers with muddy banks with Chenopodion rubrii p.p and Bidention p. p. vegetation and 6410 Molinia meadows on calcareous, peaty, clayey-silt-laden soils (Molinion cerulaeae) (Wojciech 2004). The new locality in Montenegro (Semolj saddle) is far away of its adjacent populations in Croatia, Slovenia, Bosnia and Hercegovina and Albania. This can be explained by the fact that this species is able to long distance distribution by birds, and also by the fact that wetlands of Montenegro and their surroundings are insufficiently explored. Moreover, peat bogs in southeastern Europe are sparse and relict habitats, scattered across the area in rare localities.

\section{Conclusion}

Quaking bogs in Semolj with surroundings (beech forest), as well as other smaller bogs in Montenegro require more detailed and comprehensive botanical research. Future research will be focused on confirmation of the presence of Eleocharis carniolica in other similar habitats in Montenegro. Also, all populations of E. carniolica on the saddle Semolj will be estimated and observed according to their size and dynamics.

\section{Acknowledgment}

The authors are very grateful to colleague Branko Vreš, PhD from Jovan Hadži Institute of Biology ZRC SAZU in Ljubljana for his help in determination of collected specimens. The constructive comments of an anonymous referees on the manuscript also are appreciated. This research has been supported by the Montenegrin and Croatian Ministries of Science through the bilateral project "Inventory of biodiversity and conservation status of the representative peatbogs in Montenegro and Croatia”.

Snežana Vuksanović (D), https://orcid.org/0000-0003-27358101

Christian Berg (D), https://orcid.org/0000-0002-0587-3316

\section{References}

Anonymous, 1979: Convention on the Conservation of European Wildlife and Natural Habitats.

Anonymous, 1992: Council Directive 92/43/ EEC of 21 May 1992 on the conservation of natural habitats and of wild fauna and flora.

Anonymous, 2002: Pravilnik o uvrstitvi ogroženih rastlinskih in živalskih vrst v rdeči seznam (Uradni list RS 82/2002), pp. 5-20.

Anonymous, 2013: Ordinance on Strictly Protected Species [In Croatian]. Official Gazette 144/13.

Barina, Z., Pifkó, D. \& Mesterházy, A. 2011: Contributions to the flora of Albania, 3. Willdenowia 41(2): 329-339.

Biological Diversity Act, 2002: Promulgated. - State Gazette No. 77/9.08.2002 [In Bulgarian].

Birks, H. J. B. \& Walters, S. 1972/1973: The flora and vegetation of Barno jezero, Durmitor, Montenegro. Glasnik Republičkog Zavoda Zaštite Prirode i Prirodnjačkog Muzeja u Titogradu 5: 5-23.

Blaženčić, J. 2007: Floristički pregled slatkovodnih makrofita u Crnoj Gori. - Glasnik republičkog zavoda za zaštitu prirode 29-30: 19-91.

Burić, M., Micev, B. \& Mitrović, L. 2012: Atlas klime Crne Gore. Crnogorska Akademija Nauka i Umjetnosti, Podgorica, 132 pp.

Casper, S. J. \& Krausch, H. D. 2008: Pteridophyta und Anthophyta, 1. Teil: Lycopodiaceae bis Orchidaceae. Spektrum Akademischer Verlag, Heidelberg, 403pp.

EUROPEAN COMMISSION DIRECTORATES GENERAL, 2007: Interpretation manual of European Union habitats, 2007. European Commission Directorate General for the Environment Nature and Biodiversity, Brussels.

González-Elizondo M. S. \& Tena-Flores J. A. 2000: Eleocharis (Cyperaceae) in the New World. In: Wilson K. L. \& Morrison D. A. (eds.), Monocots: Systematics and Evolution. CSIRO Publishing, Collingwood, pp. 637-643.

Govaerts R., Simpson D. A., Bruhl J. J., Egorova T., Goetghebeur P. \& Wilson K. 2007: World Checklist of Cyperaceae. Sedges. Kew, Royal Botanic Gardens, Published on the Internet. http://apps.kew.org/wcsp/

Hadžiablahović, S. 2004b: The contribution to the flora of Montenegro. Glasnik republičkog zavoda za zaštitu prirode 27-28: 7-17.

Jovanović, B., Jovanović, R. \& Zupančič, M. 1986: Prirodna Potencijalna Vegetacija Jugoslavije (Komentar karte M 1:1000.000), 18 Kongres IUFRO Yu 86, Ljubljna, 122 pp. 
Kalezić, M., Mirković, M. \& Škuletić, D., 1973: Osnovna geoološka karta 1 : 100 000, Tumač za list Šavnik K 34 - 39. Savezni geološki zavod, Beograd, 65 pp.

Kestemont B. 2010: Red list of Belgian species. [http://www.biodiv.be/ biodiversity/threats/fol036020; accessed September 2015]

Király, G. (ed.): 2007: Vörös Lista: A magyarországi edényes flóra veszélyeztetett fajai [Red List of the Vascular Flora of Hungary]. Saját kiadás, Sopron, pp. 73.

Kocjan, J. M. 2014: Prispevek k poznavanju razširjenosti nekaterih redkih, ogroženih ali drugače zanimivih taksonov v flori Slovenije - II, Hladnikia 33: 31-63.

Kopeć, D. \& Michalska-Hejduk, D. 2012: How threatened is the Polish wetland flora? Oceanological and Hydrobiological Studies 41(3): 79-89.

Lansdown, R. V. 2013. Eleocharis carniolica. The IUCN Red List of Threatened Species 2013:e.T161832A5501732.http://dx.doi. org/10.2305/IUCN.UK.20111.RLTS.T161832A5501732.en

Lastrucci, L. \& Becattini, R. 2009: La vegetazione delle aree umide presso Bosco ai Frati (Firenze, Toscana). Atti Soc. Tosc. Sci. Nat., mem., Serie B 115: 57-67.

Milanović, Đ., Brujić, J., Đug, S., Muratović, E. \& Lukić Bilela, L. 2015: Vodič kroz tipove staništa BiH prema Direktivi o staništima EU, Prospect C\&S s.a., Brussels, Belgium, 185 pp.

Parolly, G.1995: Ergänzungen zur Flora von Montenegro. Wildenowia 25: $57-74$

Petrović, D., Hadžiablahović, S., Vuksanović, S., Mačić, V. \& Lakušić, D. 2012: Catalogue of habitat types of EU importance of Montenegro, Podgorica-Beograd-Zagreb, 116 pp.

LIFE III, Swiss SDC, Dutch BBI/Matra 2008-2009: Protection of Biodiversity of the Sava River Basin Floodplains - Habitat Interpretation Sheets Natura 2000 habitat types occurring along the Sava River, 129pp.

Niklfeld, H. \& Schratt-Ehrendorfer, L. 1999: Rote Liste gefährdeter Farn- und Blütenpflanzen (Pteridophyta und Spermatophyta) Österreichs. 2. Fassung. In: H. Niklfeld (Ed.), Rote Listen gefährdeter Pflanzen Österreichs, 2. Auflage. Grüne Reihe.

Pulević, V. 2005: Građa za vaskularnu floru Crne Gore, Dopuna "Conspectus Florae Montenegrinae" J. Rohlene. Republički Zavod za zaštitu prirode Crne Gore, Posebna izdanja, Knjiga 2, Podgorica, $218 \mathrm{pp}$.

Rohlena, J. 1942: Conspectus Florae Montenegrinae. Preslia Vestnik Česke Botanicke Společnosti v Praze, Praha, 506 pp.

Rossi G., Montagnani C., Gargano D., Peruzzi L., Abeli T., Ravera S., Cogoni A., Fenu G., Magrini S., Gennai M., Foggi B., Wagensommer R.P., Venturella G., Blasi C., Raimondo F. M. \& Orsenigo S. (eds.) 2013: Lista Rossa della Flora Italiana. 1. Policy Species e altre specie minacciate. Comitato Italiano IUCN e Ministero dell'Ambiente e della Tutela del Territorio e del Mare.
Svenson, H. K. 1929: Monographic studies in the genus Eleocharis. I. Rhodora 31: 121-135, 152-163, 167-191, 199-219, 224-242.

Svenson H. K. 1932: Monographic studies in the genus Eleocharis, II. Rhodora 34: 193-203, 215-227.

Svenson H. K. 1934: Monographic studies in the genus Eleocharis. III. Rhodora 35: 377-389.

Svenson H. K. 1937: Monographic studies in the genus Eleocharis. IV. Rhodora 39: 210-231, 236-273.

Svenson H. K. 1939: Monographic studies in the genus Eleocharis. V. Rhodora 41: 1-19, 43-47, 90-110.

Stoeva, M. 2009: Eleocharis carniolica. In: Petrova, A. \& Vladimirov, V. (eds): Red list of Bulgarian vascular plants. Phytologia Balcanica 15(1): 63-94.

Szatmari, P. M., Mladin, L., Grec, A., Sicora, O. \& Sicora, C. I. 2014: Preliminary data on the distribution and floristic composition of wetland habitats in Sălajcounty. Studia Universitatis "Vasile Goldiș", Seria Ştiințele Vieții, Vasile Goldis University Press, 24 (3): 311-315.

Šegota, V. \& Alegro, A. 2016: New finding of the red listed Eleocharis carniolica Koch in Croatia. Glas. Hrvatskog botaničkog društva 4(1): $30-31$.

Topić, J. 2005: Eleocharis carniolica Koch. In: Nikolić, T. \& Topić, J. (eds.): Crvena knjiga vaskularne flore Hrvatske. Ministarstvo kulture, Državni zavod za zaštitu prirode, Zagreb, pp. 318-319.

Turis P., Kliment J., Feráková V., Dítě D., Eliáš P. Jr., Hrivnák R., Koštál J., Šuvada R., Mráz P. \& Bernátová D. 2014: Red List of vascular plants of the Carpathian part of Slovakia. Thaiszia - J. Bot. 24: $35-87$.

Verloove, F. 2015: Eleocharis engelmannii and E. obtusa (Cyperaceae), two recent acquisitions from series Ovatae in Belgium. Dumortiera 107: 25-30.

Vreš, B. 2004: Eleocharis carniolica W. D. J. Koch - kranjska sita. In: Čušin, B. (ed.): Strokovna izhodišča za vzpostavljanje omrežja Natura 2000 v Sloveniji. Rastline (Pteridiophyta in Spermatophyta). Elaborat. Ljubljana, Biološki inštitut ZRC SAZU, pp. 90-100.

Walters, S.M. 1980: Hydrocharitaceae. In: Tutin et al. (eds.), Flora Europaea 5, Cambridge University Press, Cambridge, pp. 3-5.

Witkowski, Z. J., Król, W., Solarz, W., Kukuła K., Okarma H., Pawłowski J., Perzanowski K., Ruzicka T., Sandor J., Stanova V., Tasenkevich L. \& Vlasin M. 2003: Carpathian List of Endangered Species. WWF and Institute of Nature Conservation, Polish Academy of Sciences, Vienna-Krakow, 68 pp.

Wojciech, P. 2004: Eleocharis carniolica W. D. J. Koch - Ponikło kraińske. In: Sudnik-Wójcikowskiej B., Werblan-Jakubiec H. (eds.): Gatunki roşlin. Poradniki ochrony siedlisk i gatunków Natura 2000 podręznik metodyczny. Tom 9. Ministerstwo Ârodowiska, Warszawa, s. 116-121. www.natura2000.mos.gov.pl/natura 2000/pl/poradnik.php. 